\title{
Credit Risk and Macroeconomic Interactions: Empirical Evidence from the Brazilian Banking System*
}

\author{
Gustavo José de Guimarães e Souza ${ }^{1}$, Carmem Aparecida Feijó \\ ${ }^{1}$ University of Brasília, Catholic University of Brasília, Banco do Brasil, Brasília, Brazil \\ ${ }^{2}$ Federal Fluminense University, Niterói, Brazil \\ E-mail: gd2362@columbia.edu, cfeijo@terra.com.br \\ Received July 25, 2011; revised August 29, 2011; accepted October 15, 2011
}

\begin{abstract}
In Brazil, the credit is characterized by excessive cost and limited supply and the main reason is the high default risk embedded in the spread. This paper concludes that the level of economic activity and the basic interest rate are factors with great influence on the default risk. Additionally, the paper also analyzes the reaction of the financial sector to structural risks, suggesting a new approach to credit risk. The assumption that credit risk is the result of an interactive process between banks and the economic environment is confirmed for the period from 2000 to 2006 in Brazil. The results also point to differences in the behavior of private and public banks.
\end{abstract}

Keywords: Credit Risk, Macroeconomics, Financial Sector, Corporate Risk Management

\section{Introduction}

Despite efforts to monitor and manage credit risk, this risk often reaches high levels and can harm individual banks, the financial system and consequently the economy as whole. An adequate supply of credit at low risk levels is important for a country's economic performance. According to the [1-8], bank spreads are directly related to the default risk. Indeed, this risk is the main component determining bank spreads.

The causes of the risk of defaulting on bank loans can be divided into two groups: macroeconomic (or structural) factors and microeconomic (or idiosyncratic) factors. While the first group is linked to the general state of the economy, which in turn affects the economic parameters employed in credit analysis, the second group is related to the individual behavior of each bank and its borrowers.

Structural factors are extremely important in credit risk analysis (see, for instance, [9], in developing or emerging markets. In developed markets, the decline in the quality of credit usually occurs gradually as part of the economic cycle, giving time for banks to increase their provisions for nonperforming loans in a determined period. In emerging markets, the quality of credit can

\footnotetext{
*The views expressed in this paper are those of the authors and not
} necessarily those of the Banco do Brasil. deteriorate much more rapidly [10]. This occurs due to the weaker economic and political stability of emerging markets, causing the scale of any change generally to be much greater. These sudden changes affect the monetary environment and hamper the operation of loan portfolios by banks in emerging markets. A possible manifestation is a high bank spread as a way to preserve banks' financial health. The greater possibility of drastic economic reversals induces banks to prefer conservative leverage and high earnings in response to the excessive risks incurred.

In light of this scenario, this paper examines how the economic environment influences the default risk of banks' loan portfolios. We assume that systemic oscillations - which affect loan portfolio risk - are not absorbed passively by banks. On the contrary, they take an active posture, i.e., they respond to the effects produced by the macroeconomic scenario by constantly seeking opportunities for gain or protection. Thus, we investigate the entire interactive process between the macroeconomic dynamic and banks regarding credit risk.

The first part of this paper focuses specifically on the first group of factors - the various ways the macroeconomic situation affects bank credit risk. The next part examines the relationship between microeconomic factors and credit risk, specifically how idiosyncratic risk can be conditioned by banks to mitigate systematic risk. 
Therefore, besides the systematic risk present in lending transaction caused by macroeconomic fluctuations, there is also a remaining element of risk related to the profile of the bank itself and its borrowers, called idiosyncratic or microeconomic risk. Because idiosyncratic risk is determined by the intrinsic characteristics of each borrower and lending institution, this type of portfolio risk can be adjusted by banks for various purposes. This is the heart of the question examined in this paper, in an innovative way: in the final analysis, reducing risk depends on the stance of banks. The relation between banks and macroeconomic oscillations regarding credit risk is interactive. This means to say that although the macroeconomic environment affects the portfolios of all banks, they react differently to obtain the best opportunities or to protect themselves.

This paper is divided into three sections besides this introduction and the concluding remarks. The first explains the methodology employed. The second examines the dynamic effects of economic shocks on bank credit risk, while the third discusses the various relations between microeconomic aspects tangential to credit risk and the macroeconomic dynamic, and observes how banks interact with the economic situation to protect themselves and maximize their profits.

\section{Methodology, Data and Tests}

\subsection{Calculation of Credit Risk}

Credit risk has been a determining factor of the high cost of banking transactions and also of the difficulty of obtaining loans. Therefore, the risk measured here is the main component of the bank spread in the country. However, its measurement is not trivial. In this paper, the average credit risk is obtained by the formula:

$$
\text { Credit Risk }{ }_{i}=\frac{\mathrm{PBL}_{i}}{{\text { Loan } \text { Portfolio }_{i}}}
$$

where: PBL (Provision for Bad Loans) is the amount appropriated to cover part of the credit risk incurred by banks for expected losses. This is the minimum provision established by Resolution 2682 of 1999 from the Banco Central do Brasil (BCB-Brazilian Central Bank), classified from AA to $\mathrm{G}^{1}$ for each bank or conglomerate $i$, and Loan Portfolio is the amount of credit at risk of bank or conglomerate $i$.

Therefore, the credit risk is the percent of loans a bank

\footnotetext{
${ }^{1}$ The absence of level $\mathrm{H}$ is because the percentage of provision for this is $100 \%$. There is no longer any uncertainty, because the loans are already in default according to the model.

${ }^{2}$ Loans are considered to be in default when an equal provision is required.
}

expects to go unpaid ${ }^{2}$. The minimum percentages are applied on the loan portfolio to establish the amount expected to not be repaid ${ }^{3}$.

Given that the regulatory requirement for provisioning based on internal models is standardized by the BCB and in line with the accord proposed by the Basel Committee, to ensure the comparability of the results generated, this credit risk measure can be adopted for all Brazilian lending institutions, because they are obliged to provide monthly information on their loan portfolios to the BCB.

\subsection{Data Methodology}

The main distinction regarding credit risk between different types of banks in emerging markets tends to be between public (government controlled) and private banks [10]. We thus chose to segment the analysis between public and private banks ${ }^{4}$.

The calculation of the credit risk according to the methodology followed in this paper relies on information on loan portfolios provided by banks to the BCB monthly, but only disclosed publicly every three months, through the Quarterly Financial Information (IFT) at the BCB Internet site. However, in line with the monthly frequency of other macroeconomic variables employed in this study and the greater degree of freedom for the estimates, we obtained a customized database from the BCB containing monthly information on lending operations disaggregated by financial institution and risk interval.

Therefore, the final database consists of lending operations disaggregated by risk interval, financial institution and type of control, from March 2000 to June $2006^{5}$. We calculate two risk series: one for public banks (RISK1PUB) and one for private banks (RISK1PRIV). Besides these two series divided by segments, the series of interest include macroeconomic indicators of the money market and the real economy. They are: Selic Rate-basic interest rate (SELIC); Reserve Requirement (RESREQ); Spread (SPREAD); Country Risk (EMBI);

${ }^{3}$ The default risk is the main element in credit risk modeling and can be defined as the probability of the incapacity of the borrower to honor the respective debt commitments under the previously established contractual terms. Hence, the credit risk calculated is the risk of default, not of loss. The debtor may default by delaying payment without there being a total or even partial loss for the bank. The loss only comes later if payment is not made at all. Nevertheless, default is an undesirable factor a priori for the bank, which wants to receive payment under the agreed conditions and time frame. This risk is part of the composition of the spread. The actual loss can be calculated using a percentage of the amount in default, but it does not change the path (important to this work), only the level.

${ }^{4}$ This division is also used by the BCB in some studies in reports on the banking system and credit. As will be seen from the results of this work the division by type of control is coherent.

${ }^{5}$ Data from 2007 were affected by the financial crisis, and thus are not used in this paper. 
Unemployment (UNEMP); Output (OUTPUT); Lending to Assets Ratio (LENDTOASSETS); Percentage of Loans to Individuals (PERLOANIND); Real Credit Operations by type of bank (REALCREDPUB and REALCREDPRIV); Percentage to Individuals for public institutions (PERCINDPUB) and privately controlled institutions (PERCINDPRIV). We seasonally adjusted (SA) the series by the X12-ARIMA iterative moving averages technique (multiplicative model) developed by the $[11]^{6}$. All the series are expressed in natural logarithms (L), for the purpose of smoothing out the behavior of the series, demonstrating the elasticities of the variables directly when used in the equations and simplifying some algebraic procedures of the econometric methods employed in the following sections ${ }^{7}$.

\subsection{Unit Root and Stationarity Tests}

Before carrying out the econometric modeling and analyses, we tested the series to check for the existence of stationarity. We examined how the stochastic process generating the series behaved over time, i.e., investigated the order of integration of the series. The purpose was to avoid possible spurious results from the models. Due to the importance of the presence or not of stationarity for the analyses that follow, including the possibility of cointegration, special attention is warranted. We therefore applied - concomitantly with the visual analysis of the series - the following unit root tests: augmented DickeyFuller (ADF, t-test), Phillips-Perron (PP, z test) and trend-adjusted Dickey-Fuller (DF-GLS), besides the KPSS stationarity test proposed by $[12]^{8}$. We defined whether or not to include the constant and/or trend, besides the number of lags for each series, according to the Schwarz criterion (SC), and ascertained the statistical significance of the parameters estimated, always going from the general to the particular dynamic. In inconclusive situations we opted for analysis by the three unit root tests.

According to Table A.1, the series LRESREQ, LEMBI, LREALCREDPUB_SA and LREALCREDPRIV_SA are classified as an order-one integrated processes, or $I(1)$, by the four tests applied (with $90 \%$ confidence). Although the KPSS stationarity test does not confirm the results of the ADF, PP and DF-GLS tests for the series in

\footnotetext{
${ }^{6}$ We decided to seasonally adjust the original series instead of using the series that were already seasonally adjusted, to ensure the homogeneity of the adjustment procedure.

${ }^{7}$ For the series on interest rate, inflation and real interest rate, we added one to the value of the original rate before taking the natural logarithm, to produce the interest factor, inflation factor and real interest rate factor, respectively.

${ }^{8}$ Following the suggestions of [13], we adopted the $10 \%$ significance level, and in case of a contradiction in the results, preference went to the unit root tests.
}

level LRISK1PUB_SA, LSPREAD and LUNEMP_SA, we give preference to the results of the unit root tests. The same rule we used for the series LRISK1PRIV_SA, LSELIC, LOUTPUT_SA, LPER-CINDPUB_SA and LPERCINDPRIV_SA and then are classified as I(1). The series LLENDTOASSETS_SA and LPERLOANIND_ SA are also considered to be order one integrated by the majority of the tests. Regarding the differentiated series, the results indicate stationarity for all. Thus, we decided for non-stationarity of the series in level, i.e., we considered $I(1)$ processes.

\section{Impact of Shocks on Bank Credit Risk}

In this section we seek to verify how macroeconomic factors affect banks' credit risk according to type of control (government or private). We examine how structural movements affect bank credit risk, and consequently whether the movements expected by the economic theory are borne out for Brazil over the time interval studied.

For a careful examination of bank credit risk in Brazil starting in 2000, we use the approach of simultaneous equations, more specifically the Vector Autoregression (VAR) model. This approach permits verifying the interrelationships of the variables, making use of two empirical analyses: impulse-response functions and decomposition of the variance. The first analysis permits observing the response of a specific variable to the occurrence of a shock or innovation. The second enables decomposing the participation of each variable in understanding the changes in the others [14].

As shown in Table A.1, all the series of interest are $I$ (1). The simple differentiation of the variables (cointegrated) to resolve the non-stationarity problem of the series causes a relevant loss of economic information over time. Therefore, in cases where the inexistence of a cointegrating vector is rejected, we add information regarding the long-term path of the VAR series, to generate a more robust Vector Error Correction (VEC). Another argument in favor of using VEC in such cases is that the dynamic interactions of the variables tend to change in response to each flow in which they are inserted in the system [15].

To investigate the effects on risk of shocks to key variables from the real and monetary markets, we estimate a set of simultaneous equations, in which the equation of interest contains the following basic structure:

$$
\begin{gathered}
\text { LRISK1_SA = } f(\text { LUNEMP_SA, LOUTPUT_SA, } \\
\text { LSELIC, LRESREQ, LSPREAD, LRISK1_SA })
\end{gathered}
$$

with the expected signs expressed by the following partial derivatives: 


$$
\begin{aligned}
& \partial f / \partial \text { LUNEMP_SA }>0, \partial f / \partial \text { LOUTPUT_SA }<0, \\
& \partial f / \partial \text { LSELIC }>0, \partial f / \partial \text { RESREQ }<\text { or }>0, \\
& \partial f / \partial \text { LSPREAD }>0 \text {, and } \partial f / \partial \text { LRISK1_SA }>0
\end{aligned}
$$

As said before, the analysis is divided into two broad categories, public (government controlled) and private banks.

\subsection{VEC Model—Public Banks}

Given the unit order of integration for the variables involved, we test for the existence of one or more cointegration vectors by the systematic method proposed by $[16,17]$. The first step entails defining the number of lags. The choice is made based on the following criteria: modified maximum likelihood (LR), final prediction error (FPE), Akaike information (AIC), Schwarz (SC) and Hannan-Quinn (HQ) ${ }^{9}$.

According to all these tests (Table A.2) ${ }^{10}$, the ideal would be to use two lags in the VAR, and hence one lag in the Johansen test. The residuals of these models are not autocorrelated. As suggested by [18], the model considered should be that which provides the lowest values for the trace statistics and the maximum of the value itself. In this case, the results converge.

We chose to include the deterministic components (constant and trend) in the cointegrating relation and to omit the trend in the autoregressive vector based on the Schwarz and Akaike criteria and the graphical analysis of the variables involved ${ }^{11}$.

To determine the number of cointegration vectors, we use the trace statistics and maximum eigenvalue, which indicate, respectively, three and two cointegrating relations. Although the number of relations varies according to the test, the important fact is that it is impossible to reject the existence of cointegration relations, i.e., it is suitable to use a VEC model for the case in question ${ }^{12}$. The suggestion of [22], of placing greater reliance on the result of the maximum eigenvalue statistic, is ratified by the Schwarz criterion and diagnostic tests (both on the underlying VEC), as well as by the principle of parsimony. All indicate the use of two cointegration vectors.

The existence of cointegrating vectors imposes the transformation of the VAR model into a VEC model to analyze the dynamic interrelationships.

The validity of the specification depends on the serial

\footnotetext{
${ }^{9}$ For a fuller discussion, see [14].

${ }^{10}$ For all the definitions of the number of lags in this study we also tested up to eight lags. However, the four last lags in no case caused any improvement according to the criteria adopted.

${ }^{11}$ For more information on the procedure followed, see $[19,20]$.

${ }^{12}$ According to [21], the divergence in the indication of the number of cointegration vectors by these two tests is a common consequence of small samples.
}

non-correlation, normality and homoskedacity of the residuals. To verify these aspects we run various tests. Visual analysis leads to the supposition of white noise. The Portmanteau test and Lagrange multiplier (LM) test do not reject the null autocorrelation. We carry out the White test for heteroskedacity, estimated with and without the inclusion of crossed terms. With both specifications there are insufficient reasons to reject the null hypothesis of homoscedastic residuals ${ }^{13}$. To diagnose normality, we perform the Lutkepohl and Doornik-Hansen tests. These do not evidence the presence of multivariate non-normality of the residuals. It is also desirable to have a stationary system of multiple equations. The stationarity of the components of a VAR model can be verified through the eigenvalues of the long-term matrix. For a $p$ dimensional VAR with $d$ lag(s), there are $p . d$ eigenvalues, in which $p$ is the number of endogenous variables. If all the eigenvalues are within the unit circle, the parameters can be considered stable. In the case of a VEC, $p$-r eigenvalue(s) must be on the unit circle, where $r$ is the number of cointegrating relations ${ }^{14}$. In this specific case, there are six endogenous variables and two cointegration vectors, hence four unit roots. The other eigenvalues are within the unit circle.

It is known that in the VAR/VEC methodology the order of the variables influences the results from the impulse-response and decomposition of variance analyses ${ }^{15}$. Because of this, to avoid arbitrary ordering we apply the Granger causality/block exogeneity Wald tests. This procedure calculates the joint significance of each lagged endogenous variable for each equation of the model. From the chi-square statistic, the variables are ordered from the more exogenous to the more endogenous (from the lower to the higher values of the statistic ${ }^{16}$. The results are available in Table A.3.

The proposed order is unemployment, output, Selic, reserve requirement, credit risk (public banks) and spread. Consequently, as conjectured in the theoretical model (2), the variable of interest in this study-credit risk-is affected contemporaneously by all the variables tested except spread. Therefore, besides being statistically consistent, this order makes theoretical sense.

After we estimated the VEC model and carried out the robustness tests and ordered the variables, we analyzed the impulse-response functions and the variance decomposition. Because of the monthly frequency of the data, we present the analyses for a period of twelve months after the occurrence of the shock. The stability of the

\footnotetext{
${ }^{13}$ The results mentioned had a confidence level of 95\% (and did not change at $99 \%$ ).

${ }^{14}$ See [14].

${ }^{15}$ In the specific case where the covariance matrix of the residuals is a diagonal matrix (or similar to one), the ordering is not important.

${ }^{16}$ For more details, see [22] and/or [23].
} 
effects after one year justifies this horizon.

According to [22], impulse-response functions show the long-term effects of time series when there is an exogenous shock in one of the model's variables. Therefore, the impulse-response functions here indicate the reaction of bank credit risk when there is some exogenous innovation in the variables incorporated in the model.

The functions here are obtained by the traditional Cholesky decomposition. For comparison of the previously defined order, we also calculate the impulse-response functions by the method proposed by [24]. These authors constructed a group of orthogonal innovations that do not depend on the order. These special functions are known as generalized impulse-response (GIR) functions. The method does not impose a priori restrictions regarding the relative importance of each variable on the transmission process. The comparison between the two methods enables ratification or rectification of the previous ordering.

In this form, we examine the relationship between bank credit and each of the macroeconomic factors by computing the impulse-response functions (through Cholesky decomposition and GIR), derived from the estimation of the six equations of the VEC model. An innovation in any of the variables must be interpreted as an unexpected economic shock (measured by the impulse of one standard deviation). Thus, the functions trace out the effect on risk caused by a contemporaneous shock in each of the endogenous variables. The Figure 1 allows comparison of the magnitude of the responses of default risk to changes in this variable itself and the other variables.

In general, we did not find large differences in the results obtained by the two methods ${ }^{17}$. Although the response of credit risk is more sensitive by the generalized method, the format of the impulse-response functions is similar for each variable, demonstrating good adherence of the order chosen using the Cholesky methodology. We should also point out that in all the cases the impulses cause lasting effects, which become stable only after one year.

A shock in risk volatility generates a positive and increasing reaction of credit risk starting in the first month after the shock. The same occurs with an impulse from unemployment, where the effect is positive but declining after the fifth month. A shock from output causes a significant reduction in risk-as would be expected by the theory. In turn, innovations in the monetary variablesSelic or reserve requirement-raise credit risk, with the effect from the former (the basic interest rate) being the greatest.

\footnotetext{
${ }^{17}$ An impulse in the variable itself (risk) to which the response is obtained generates identical functions.
}

A shock in the reserve requirement reduces risk in the first month, but raises it in the following months at successively rising and declining rates. In general, shocks in the Selic rate and industrial output have the strongest effect on risk.

An important observation is the reduction of credit risk of public banks in response to a shock in the bank spread. An anticipatory effect of the spread on the expectation of default is found in public banks. This suggests there may be a shift in default expectations present in the constitution of the spread and the risk measure of public banks. Another explanation would be that the greater volatility in the spread prompts defensive stances by public banks regarding extending new loans, and consequently reduces the risk level.

However, analysis of the confidence intervals (99\%) of the impulse-response functions by the decomposition method shows that only output, Selic and credit risk itself generate significant effects. In the case of the reserve requirement, the response is significant only in the second month after the shock.

While the impulse-response function traces out the effect of a shock in one endogenous variable on another variable, the variance decomposition separates the change in one variable among the components of the shock. It thus provides information on the relative importance of each innovation that affects the model's variables. In essence, the objective of the technique is to explain the participation of each variable of the model in the variance of the residuals of the model's other variables [19].

According to Table 1. which shows the variance decomposition for twelve months after a shock, most of the behavior of public banks' credit risk is due to the Selic rate (55.11\%), to credit risk itself (31.88\%) and to indus-

Table 1. Decomposition of the variance (\%) for the credit risk of public banks.

\begin{tabular}{|c|c|c|c|c|c|c|}
\hline Period & Unemp. & Output & Selic & Reserve Req. & Cred.Risk Pub. & Spread \\
\hline 1 & 0.14 & 0.44 & 9.72 & 9.33 & 80.37 & 0.00 \\
\hline 2 & 0.10 & 7.38 & 21.69 & 5.34 & 65.40 & 0.08 \\
\hline 3 & 1.45 & 10.55 & 30.11 & 3.48 & 53.51 & 0.87 \\
\hline 4 & 2.56 & 10.48 & 36.03 & 2.90 & 46.50 & 1.53 \\
\hline 5 & 3.01 & 10.31 & 40.19 & 2.52 & 41.96 & 2.00 \\
\hline 6 & 3.01 & 10.10 & 43.47 & 2.16 & 39.11 & 2.14 \\
\hline 7 & 2.83 & 9.81 & 46.25 & 1.83 & 37.14 & 2.14 \\
\hline 8 & 2.63 & 9.47 & 48.62 & 1.57 & 35.61 & 2.10 \\
\hline 9 & 2.43 & 9.12 & 50.64 & 1.36 & 34.40 & 2.05 \\
\hline 10 & 2.26 & 8.78 & 52.37 & 1.19 & 33.40 & 2.00 \\
\hline 11 & 2.10 & 8.47 & 53.84 & 1.05 & 32.58 & 1.95 \\
\hline 12 & 1.96 & 8.20 & 55.11 & 0.94 & 31.88 & 1.90 \\
\hline
\end{tabular}

Note: Order of the variables: Unemployment, Output, Selic, Credit Risk of Public Banks and Spread. 

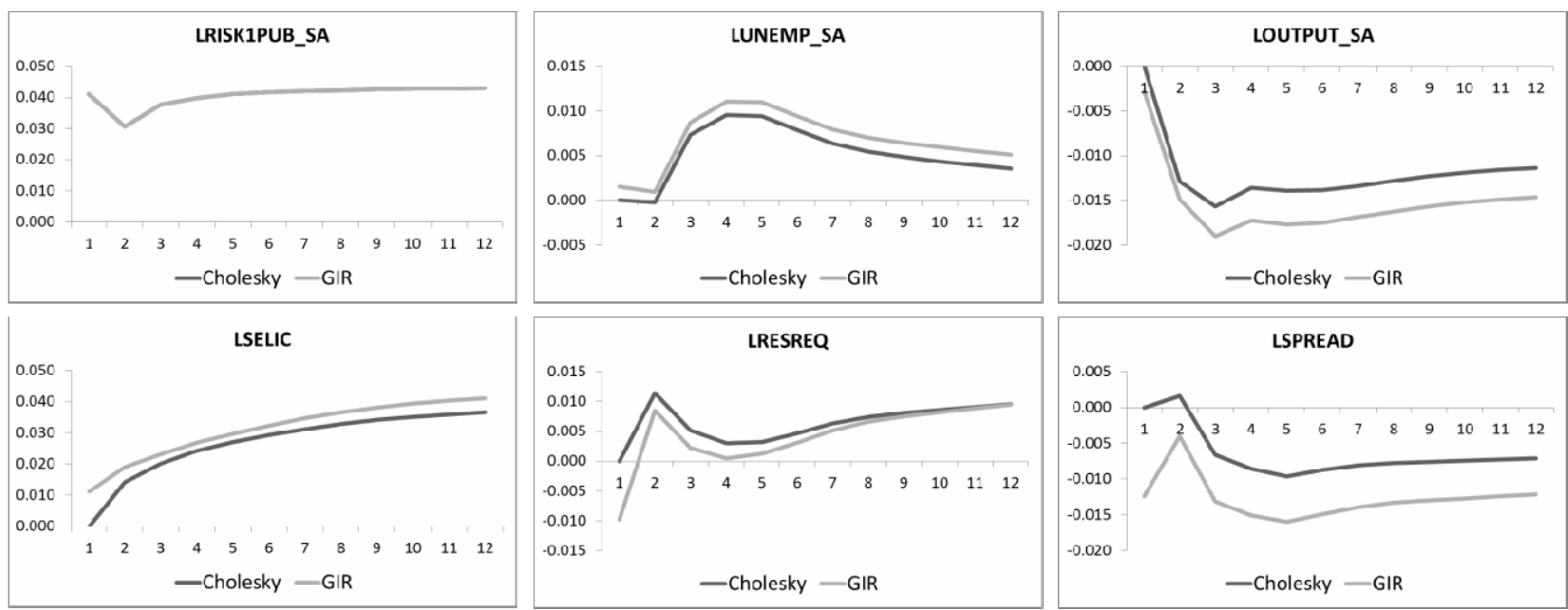

Figure 1. Response of risk to impulses (one SD) in the other variables-public banks.

trial output (8.20\%). The other variables have similar lesser effects: unemployment (1.96\%), spread (1.90\%) and reserve requirement $(0.94 \%)$. So, the results found from the impulse-response function and variance decomposition show that the main macroeconomic determinants of credit risk for public banks in Brazil are the Selic rate and output. While a positive shock in the former raises the credit risk, such a shock in the latter lowers the credit risk.

\subsection{VEC Model—Private Banks}

All the variables involved are I(1), according to Table A.1. Therefore, the Johansen test can be used to identify the existence of cointegrating vectors, and if this is confirmed, their suggested number. Before doing this, however, it is necessary to choose the number of lags to be used. The choice was determined by the set of criteria presented in Table A.4.

Although there was no unanimity among the lag selection criteria, the choice was the lowest (two lags in the vector autoregression model and one by the cointegration test), since this was indicated by the majority of the criteria to determine the lags (AIC, SC and HQ), by the methodology of [18], by the SC and AIC criteria of the underlying model and by the parsimony principle together with analysis of the residuals.

The option to use the constant and trend in the cointegrating relation and the constant in the VAR is based on the Schwarz and Akaike criteria from graphical analysis of the variables involved. The specification of the deterministic components utilized in the cointegration converges with that employed in the error correction model for private banks. This definition suggests, at 5\% statistical significance, the existence of a cointegration vector according to the tests of the trace and maximum eigenvalue. Faced with this, we decided to analyze the dynamic interactions of these variables in the context of a VEC model.

We examine the robustness of the model by means of a set of tests. Regarding autocorrelation, the Portmanteau and Lagrange multiplier tests do not present significant indications (at 99\% confidence) of existence. Visual analysis of the residuals corroborates this evidence. By the White tests, with and without addition of crossed terms, there are no reasons to reject the hypothesis of homoscedastic residuals. At a $1 \%$ significance level, the normality of the residuals is rejected by the Lutkepohl test, but not rejected by the Doornik-Hansen test. The six endogenous variables and the cointegrating vector impose five eigenvalues on the unit circle. However, the other eigenvalues have absolute values less than one. Therefore, the results validate the specification of the proposed model, allowing proceeding with the specific analyses of the impulse-response functions and variance decomposition.

To define a statistically consistent order, we employ the Granger causality/block exogeneity Wald tests, which are useful to determine the order of the variables according to the degree of exogeneity (Table A.5).

According to the table, the order for private banks is the following: reserve requirement, unemployment, Selic rate, industrial output, spread and credit risk. The variable of interest-credit risk - is consequently the most endogenous. In line with the structure of Equation (2), the credit risk of private banks is influenced by all the other series (including the spread), responding to shocks in the same period. Besides this, the order suggested, although not determined a priori by the theory, is coherent with it. The level of the reserve requirement is the 
most exogenous variable, since it is partly controlled by the BCB; the bank spread is affected by the macroeconomic factors selected, as is suggested by various studies of the Brazilian market; industrial output is affected by monetary policy and unemployment; and private banks' credit risk is influenced by the economic conjuncture.

For the same reasons presented for the impulse and variance analyses of public banks, we use a twelvemonth horizon for private institutions. Below the simulations are presented of shocks from the variables involved in the model private banks' credit risk. The aim is to identify the behavior of the credit risk in the face of impulses and at the same time the persistence of these effects. The responses of private banks' credit risk to shocks from each variable in the model are shown in Figure 2.

The order used for the Cholesky decomposition generates similar functions to the general impulse-response (GIR) functions ${ }^{18}$, which in turn minimizes the possible composition effects present in the orthogonal shocks. In general, the responses stabilize seven months after the simulated innovation.

The credit risk reacts positively after the shock in its volatility, but this effect declines with time, returning to a stationary stage. A simulated impulse from unemployment causes the risk to rise in the first three months, but this effect reverses in the months thereafter. Nevertheless, this effect is very near zero.

An output shock reduces the risk significantly both in the short and long range. The shocks produced by any of the monetary variables cause permanent elevations in private banks' credit risk, but in terms of magnitude, the effects generated by the Selic rate and reserve requirement are stronger than those of the spread. The same intensity is observed, in the opposite direction, from an output shock. In the case of private banks, the results corroborate those that would be expected theoretically.

The macroeconomic factors that cause significant responses (99\% confidence) are output, the Selic rate and the reserve requirement.

The second step of the examination of private banks by multiple equations concentrates on decomposition analysis of the variance of the prediction errors. This is useful by showing the evolution of the dynamic behavior of the variables over $n$ periods in the future.

The variance decomposition analysis (Table 2) indicates that the most important variables to explain the variance in bank credit risk twelve months after a shock are, besides the risk itself (36.97\%), the reserve requirement $(26.65 \%)$, output $(18.26 \%)$ and the Selic rate (13.05\%). The percentage referring to the spread remains

\footnotetext{
${ }^{18}$ In the case of a shock in the risk itself, the functions overlap in Figure 2.
}

at roughly four over a period of one year. The part of the variance explained by unemployment begins to fall after the second month, reaching $0.68 \%$ twelve months after a shock.

From joint examination of the responses to impulses and variance decomposition, it can be concluded that the most important macroeconomic variables in determining private banks' credit risk in Brazil are the reserve requirement, Selic rate and industrial output.

\subsection{VEC Model-A Bank Comparison}

The analyses carried out by the VAR model with error correction show that output and the Selic rate are determining factors of bank credit risk in Brazil, irrespective of the type of bank (public or private). Monetary tightening, measured by a rise in the reserve requirement, positively affects the risk level of all the country's banks, but the effect is stronger on private banks. Figure 3 and Figure 4 visually summarize the results obtained by the general impulse-response (GIR) function and the variance decomposition analyses for public and private banks, respectively.

As can be seen from the GIR functions shown in Figure 3, among the macroeconomic factors the strongest impacts on public banks' credit risk (positive and negative, respectively) are caused by shocks in the Selic rate and output. They also stand out in explaining the variance, besides the effect of the risk itself.

For private banks (Figure 4), the macroeconomic factors that stand out are the reserve requirement, output and the spread. The spread, despite having the weakest effect of the three, is positively related to risk, as would be expected, due to the anticipatory factor. Unemploy-

Table 2. Decomposition of the variance (\%) for the credit risk of public banks.

\begin{tabular}{|c|c|c|c|c|c|c|}
\hline Period & Reserve Req. & Unemp. & Selic & Output & Spread & Cred. Risk Priv. \\
\hline 1 & 0.08 & 0.75 & 2.04 & 0.02 & 1.25 & 95.86 \\
\hline 2 & 0.98 & 3.72 & 1.07 & 3.06 & 1.32 & 89.85 \\
\hline 3 & 6.27 & 2.77 & 0.65 & 13.79 & 2.30 & 74.22 \\
\hline 4 & 12.55 & 1.90 & 0.69 & 19.45 & 4.20 & 61.22 \\
\hline 5 & 16.85 & 1.52 & 1.53 & 21.46 & 5.17 & 53.47 \\
\hline 6 & 19.68 & 1.30 & 3.06 & 21.57 & 5.38 & 49.00 \\
\hline 7 & 21.59 & 1.14 & 4.91 & 21.09 & 5.25 & 46.02 \\
\hline 8 & 23.02 & 1.00 & 6.78 & 20.47 & 5.05 & 43.68 \\
\hline 9 & 24.18 & 0.89 & 8.56 & 19.86 & 4.85 & 41.67 \\
\hline 10 & 25.15 & 0.80 & 10.19 & 19.29 & 4.68 & 39.89 \\
\hline 11 & 25.96 & 0.73 & 11.69 & 18.76 & 4.53 & 38.33 \\
\hline 12 & 26.65 & 0.68 & 13.05 & 18.26 & 4.39 & 36.97 \\
\hline
\end{tabular}

Note: Order of the variables: Reserve Requirement, Unemployment, Selic, Output, Spread and Credit Risk of Private Banks. 

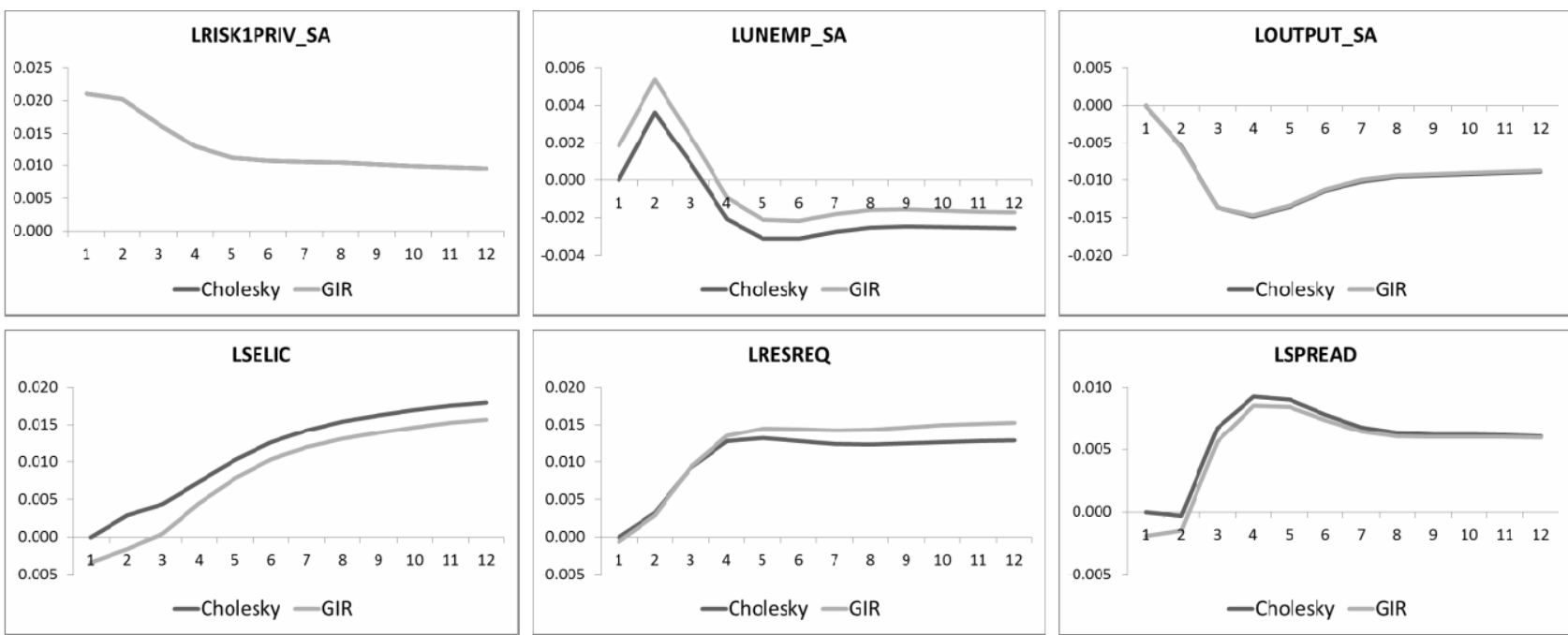

Figure 2. Response of risk to impulses (one SD) in the other variables - private banks.
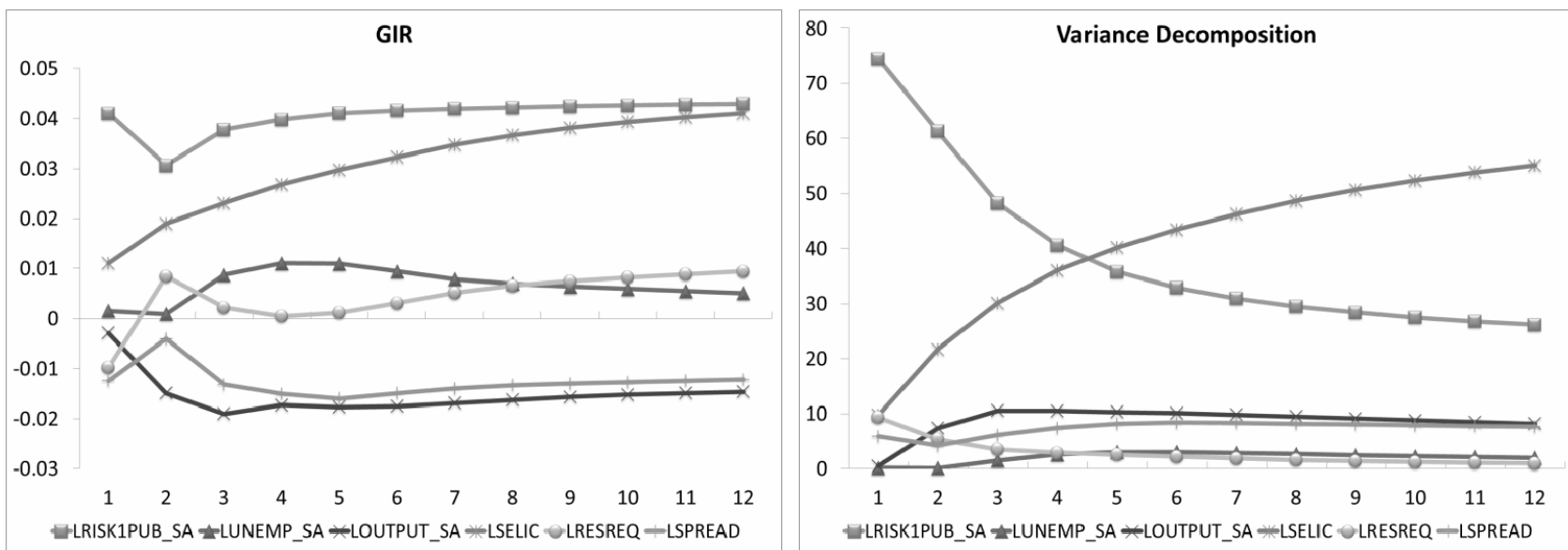

Figure 3. Impact and variance-credit risk of public banks.
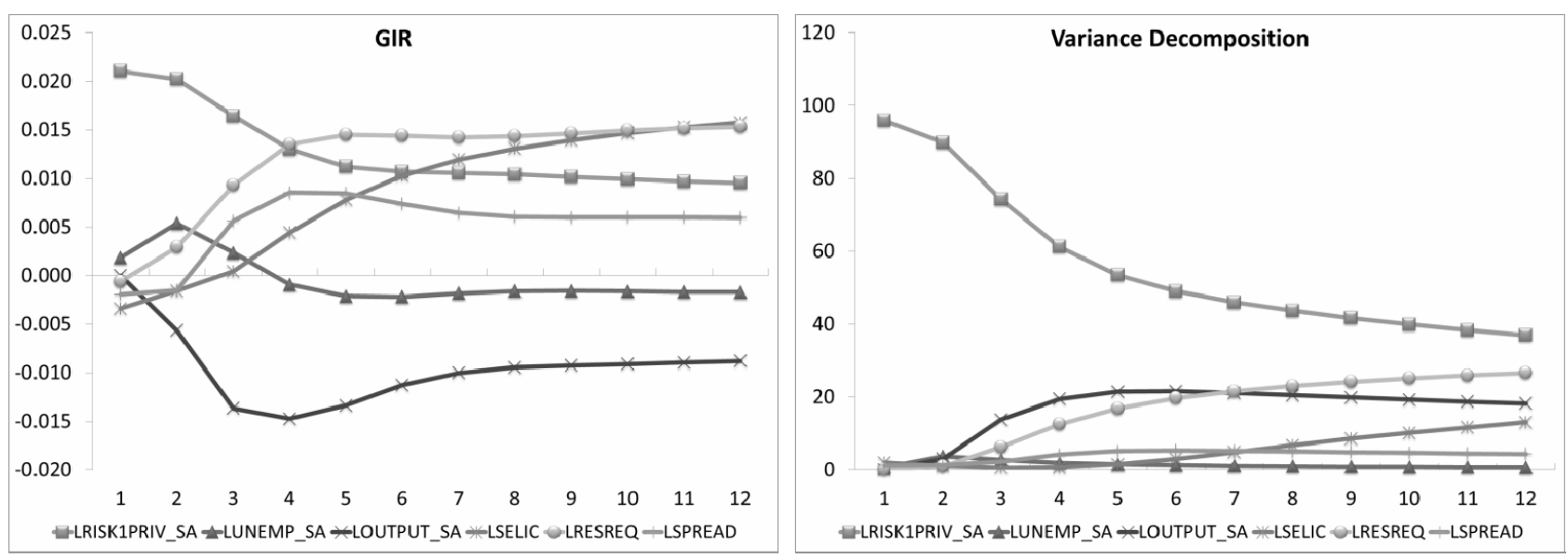

Figure 4. Impact and variance—credit risk of private banks.

ment showed a weak cyclical effect on private banks' credit risk.
Therefore, the results of the impulse-response functions and variance decomposition suggest that the basic 
interest rate and level of economic activity are the main macroeconomic determinants of bank credit risk in Brazil. If on the real side the effects on credit risk of changes in output stand out in relation to unemployment, on the monetary side the Selic rate prevails over the other variables due to its strong link with the other macroeconomic factors. Besides, since June 1999 the inflation targeting regime was adopted in Brazil, and the main instrument to the disposition of the BCB for the convergence of inflation to the target is the Selic. Reference [25] suggests that the process of building credibility in Brazil is slow, and therefore, a lower credibility implies higher variations in the interest rate for controlling inflation in Brazil.

It can also be seen that public banks are more sensitive to macroeconomic fluctuations than are private banks. The impact of factors of the structural scenario is stronger on public banks.

The next section examines the process of interaction between banks and the macroeconomic dynamic. This interactivity can be one of the causes of the distinct effect on credit risk between the two types of banks.

\section{Macro and Micro Risk-Analysis by Cointegration}

Structural factors affect the risk banks run on their loan portfolios. However, this risk is not only imposed by the economic scenario, but also by the intrinsic characteristics of their borrowers and the banks themselves. This combination of microeconomic factors is called idiosyncratic risk.

Financial institutions, in the face of the level of economic uncertainty, change their stance regarding selection of borrowers and supply of loans to presage possible changes in the level of default. This is the gist of the question. Banks are totally pro-cyclical, meaning they are more selective in their lending during periods of greater economic uncertainty, and vice versa. The partial control over the profile of their loan portfolios enables banks to maintain the risk level within an interval preestablished by them. This control occurs through the idiosyncratic risk of the loan portfolio-through the capacity to choose borrowers according to their risk profileallowing banks to offset the effects of the macroeconomic environment ${ }^{19}$. Economic downturns prompt banks to

\footnotetext{
${ }^{19}$ Control over the profile of the loan portfolio is heightened in situations where the supply of credit is lower than demand and competition is imperfect, as occurs in Brazil.

${ }^{20}$ The credit cycle follows the economic cycle. This association, including for Latin America, is discussed in [26].

${ }^{21}$ Although it is impossible for banks to alter the idiosyncratic risk of each borrower/loan, they can modify the idiosyncratic risk at the portfolio level, i.e., the microeconomic risk involved in the total loan portfolio.
}

take a defensive stance in offering credit and raise the bar for borrowers. The opposite happens in times of strong growth and reduced macroeconomic uncertainties: banks increase their lending and lower the bar for borrowers $^{20}$.

From a standpoint of managing assets according to liquidity, it can be argued that banks, in accompanying the economic cycle, direct their investments considering not only yield, but also maturity profile, liquidity and uncertain. In economic slowdowns, banks reduce their lending and/or shift their resources to other types of assets, raising their average position in more liquid assets and reducing their leverage. In periods of strong growth they prefer yield over liquidity. In other words, banks can be expected to increase their risk exposure in growth phases, becoming more willing to accept lower risk exposure margins of firms, while in crisis moments they tend to increase their preference for liquidity, independent of the expected returns from their investment projects.

Then, infers that banks have a relevant role in explaining the behavior of the economic cycle, both by accommodating demand for credit in upturns, spurring economic activity, and by contracting credit during downturns, worsening the crisis by restricting lending to companies because of their deteriorated capacity to generate cash flow.

Therefore, credit risk, besides its structural component dictated by the macroeconomic environment, is associated with the idiosyncratic aspects of borrowers themselves. Banks, although they have influence, do not have control over macroeconomic variables. However, they can change the profile of their loan portfolios to lower their risks.

Consequently, banks - although they are affected by macroeconomic risk - only can directly interfere in the microeconomic risk of their loan portfolios. This partial control over idiosyncratic risk, in the ambit of the portfolio, can be used to offset changes in the situational risk ${ }^{21}$. Increases in macroeconomic risk induce counterpart actions by banks to lower their microeconomic risk and thus to maintain their overall risk at the desired levels established by management. Banks thus act to efficiently manage the risk/return ratio of their lending operations.

We also investigate this phenomenon in Brazil in the study period. The credit risk measured in this paper, according to the methodology followed, refers to the total credit risk, i.e., both the macro and microeconomic risk. It is the risk of loan default of the portfolio, considering the characteristics of borrowers and the economic environment in which they are inserted ${ }^{22}$.

Despite the theoretical knowledge of the separation of

${ }^{22}$ Banks' internal models to determine the probability of default must take these factors into consideration according to the applicable regulations. 
risk into macro and micro components, their analytic division is complicated. Formulation of a standard measure of idiosyncratic risk of the loan portfolio separate from macroeconomic risk is not simple, despite the statistical and mathematical advances regarding risk. Here we employ measures that demonstrate the loan portfolio movements induced by banks aiming to modify their total idiosyncratic risk.

However, there is also the difficulty of obtaining information on loan portfolios broken down by type of control in Brazil. The most detailed data refer to credit operations with non-earmarked funds. However, at this level of information there is no segmentation by type of bank. For this reason, we first decided to analyze the cointegration relation between the micro and macro risk for the entire sample of banks, and then with another set of proxies to analyze this by type of bank. If it is not possible to capture the idiosyncratic risk directly, various indicators that measure banks' posture regarding changes in idiosyncratic risk can be employed as proxies.

We measure the oscillations in microeconomic risk for banks in Brazil by two loan origination series: LLENDTOASSETS_SA and LPERLOANIND_SA. We also separately use proxies to capture the movements in the loan portfolios of public and private banks to change their microeconomic risk: the amount of real lending transactions (LREALCREDPUB_SA and LREA CREDPRIV_SA) and the percentage of the portfolio dedicated to loans to individuals (LPERCINDPUB_SA and LPERCINDPRIV_SA).

In light of the empirical literature [27], we use the country risk (LEMBI) as a proxy for macroeconomic risk. We contrast this risk series with each of the proxies for changes in the idiosyncratic risk.

It is known that changes in a bank's loan portfolio are slow, given the intrinsic characteristics of loans. There is a delay between the repayment of existing loans and extension of new ones according to the latest policies defined by management. Therefore, changes in loan portfolio makeup in principle only occur over the medium and long term. To verify the relationship of two variables over the long run, cointegration analysis can be used.

We check the cointegration of the series according to the model of $[16,17]$, which uses a VAR. We know in advance that the series involved are first-order integrated processes, so cointegration can be applied. If the series are cointegrated, a long-run relationship can be said to exist between them, and the cointegration vector coefficients are long-term elasticities of banks' reaction to

\footnotetext{
${ }^{23}$ The series on lending and volume by type of borrower refer to refer to transactions in the National Financial System. However, the high representation in this system $(99.07 \%$ of total assets, with the fifty largest banks responsible for $83.90 \%$ ), ensures the quality of the proxy. The data are from June 2006 (available at the BCB site).
}

changes in the macroeconomic risk.

\subsection{Macro and Micro Risk Relation-All Banks}

We verified the cointegration between macroeconomic risk and lending levels in relation to bank assets and between macro risk and the percentage of loans to individuals for all banking institutions in the country.

\subsubsection{Relation between Country Risk and Loans to Assets Ratio}

A bank, just as any other agent whose activity is speculative and demands some degree of protection, composes its portfolio seeking to conciliate profitability with its preference for liquidity, which entails its precaution regarding the uncertainty of the results. Therefore, the composition of a bank's assets depends on its willingness to absorb risks associated with uncertain future events, more specifically the state of its expectations about these events. When the bank's evaluation is unfavorable about the future return on loans, maintenance of the value of the collateral required and behavior of market interest rates, it will likely prefer more liquid assets to traditional loans, which normally have a longer maturity profile. These decisions are related to the administration of the bank's balance sheet.

The series on credit transactions covers loans contracted at interest rates freely set by banks according to what borrowers are willing to pay ${ }^{23}$. It does not include farm credit transactions, onlending from the National Bank for Social and Economic Development (BNDES) or any other loans from government sources or compulsory reserve deposits. This series weighted by the series on bank asset levels thus gives the percentage of loans in relation to assets. An increase in lending only because of higher assets and a decrease because of lower assets is controlled. Therefore, in response to oscillations in the macroeconomic scenario, banks can extend more or less credit, and part of banking funds can be invested in other assets with differentiated risk profile instead of to make traditional loans.

The proxies used in this subsection for the micro and macroeconomic risks are, respectively, LLENDTOASSETS_SA and LEMBI. These series have a linear correlation of negative 0.39 . To estimate the cointegration vectors by the Johansen approach, we use a VAR model, with the number of lags chosen according to the majority of the criteria: LR, FPE, AIC, SC and HQ (Table A.6). These choices are in line with the parsimony principle.

The possible inclusion of deterministic terms in the VAR and the cointegration equation is determined by the Schwarz and Akaike criteria and by graphical analysis of the variables. In the case here, we chose not to assume a 
linear trend in the data and to include the constant only in the cointegration relation. This configuration indicates (at 5\% statistical significance) the existence of a cointegration relationship both by the trace statistic and the maximum eigenvalue (Table A.7).

After choosing the most suitable specification for the VAR by the criteria adopted and its subsequent approval by the robustness tests, we applied the Johansen model to estimate the cointegrating vector. The long-term relation between the ratio between lending and assets and macro risk can be described as shown below ${ }^{24}$ :

$$
\text { LLENDTOASSETS_SA }=\underset{(0.14)}{2.97}-\underset{(0.01)}{0.04} \text { LEMBI }
$$

The sign for the macroeconomic risk is negative, which is the first indication of the assumed hypothesis.

\subsubsection{Relation between Country Risk and Loans to Individuals}

According to [28] page 135, [] a bank's decision problem is how to distribute the resources they create or collect among these different items that offer specific combinations of expected monetary returns and liquidity premia, instead of just choosing between reserves and loans or of passively supplying whatever amount of credit is demanded.

The idea of managing assets according to illiquidity risk present in [29] can be extrapolated to credit risk. Given that the total amount of credit offered is mainly defined by the amount of reserves, choosing the constitution of the loan portfolio according to the different types of borrowers and their respective idiosyncratic risks is essential in managing the risk of banking assets, i.e., the overarching decision is not how much to lend, but to which borrowers.

Therefore, banks can make changes in their microeconomic risk by varying the profile of their loans. $\mathrm{Ce}$ teris paribus, changes in the loan portfolio composition can cause reductions or increases in microeconomic risk, and hence changes in overall risk.

It is known a priori that the default risk on loans to individuals is substantially higher than on loans to companies. Therefore, alterations in the portfolio percentage by type of borrower change the portfolio's idiosyncratic risk profile. It is reasonable to expect that rises in the macroeconomic risk induce reduction in the microeconomic risk, through a reduced percentage of personal loans in relation to business loans, and vice versa ${ }^{25}$.

The two proxies used here are LPERLOANIND_SA for micro risk and LEMBI for macro risk. There is a

\footnotetext{
$\overline{{ }^{24}}$ The (normalized) coefficients and standard deviation are in parentheses.

${ }^{25}$ The change in the micro-risk also occurs due to the change in concentration by type of borrower.
}

strong negative linear correlation between them $(-0.79)$. We use a VAR model to verify the existence of cointegration and estimate the possible vector(s). The joint analysis of the LR, FPE, AIC, SC and HQ criteria, shown in Table A.8, indicates the use to two lags. From visual analysis of the series, which suggests there is no deterministic trend in the data, along with application of the Schwarz criterion, we include the constant in the cointegration relation. Regarding the number of cointegration vectors, both the trace and maximum eigenvalue statistics indicate (at 5\% significance) one vector (Table A.9).

The normalized coefficients of the cointegration relation are shown in Equation (5) and represent the longterm relationship.

$$
\text { LPERLOANIND_SA }=\underset{(0.06)}{0.80} \underset{(0.00)}{0.05} \text { LEMBI }
$$

The contrary reaction through alterations in the loan portfolio composition is confirmed by the significance of the estimated coefficient. The value of this coefficient is similar to that found in estimation via the proxy LLENDTOASSETS_SA.

\subsection{Macro and Micro Risk Relation-By Type of Bank}

As can be observed, the structural factors influence the risk profile of banks' loan portfolios. This influence has some specificities regarding type of ownership. Private Banks are affected differently than ones controlled by the government.

On the matter of partial control of idiosyncratic risk, private banks have more flexibility than public ones in adjusting the risk composition of their portfolios. The greater freedom to choose assets and borrowers with the sole purpose of maximizing profits favors the risk/return strategies of private banks. Therefore, we also analyze the level of risk according to type of financial institution.

However, it is not possible to use the same series as before to capture changes in microeconomic risk, because the series are not available broken down to this level. To overcome this limitation, we use series on lending transactions in general and lending to individuals, both of which are available by type of bank.

\subsubsection{Relation between Country Risk and Lending Transactions by Type of Bank}

Although we are not working with new loan originations, a bank's total amount of credit is to a large measure defined by these. The total amount of loans is managed by the bank to ensure the expected return given the risk and to protect itself against changes in the macroeconomic 
scenario. The series employed (LREALCREDPUB_SA and LREALCREDPRIV_SA) reflect the total amount banks (public and private, respectively) choose to keep under their tutelage. Therefore, the economic scenario determines the overall credit limit of the banking institution, or its maximum risk exposure.

The new loans made in the final analysis depend on the volume of credit already made available. This credit series reflects the flow of credit transactions. It can thus be considered as a net series, i.e., the new loans made in the period minus amortizations of existing loans. Therefore, changing the (real) volume of credit at risk is another way banks react to the effects from the macroeconomic scenario.

4.2.1.1. Relation of Credit Transactions for Public Banks The series used are LREALCREDPUB_SA for micro risk and LEMBI for macro risk. The correlation is negative 0.20 , meaning there is no strong evidence of time precedence. The order of the VAR is defined according to Table A.10.

The choice to include the intercept only in the cointegration relation is due to the Schwarz criterion and to the behavior of the series in question. The trace statistic and maximum eigenvalue do not indicate the presence of cointegration (Table A.11) ${ }^{26}$. Consequently, according to the Johansen procedure, no long-term relationship can be found for the public banking sector.

\subsubsection{Relation of Credit Transactions for Private Banks}

The difference in relation to the preceding sub-item is the seasonally adjusted logged series of real lending transactions of private banks, or LREALCREDPRIV_SA. The linear correlation between this and the micro risk measured by LEMBI is negative 0.29. Table A.12 presents the statistics that permit determining the number of lags in the VAR. We chose the suggestion of the SC and HQ and thus lost fewer degrees of freedom.

The results of the tests suggest that the best model should include a constant in the cointegration relation and the VAR and a trend only in the cointegration vector. We ran various tests to ensure the robustness of the model. With this specification, both the trace and maximum eigenvalue tests (Table A.13) indicate the presence of cointegration. Based on this, the normalized coefficients for the cointegration relation can be calculated by the Johansen procedure. The equation can be expressed

\footnotetext{
${ }^{26}$ The idea is ratified by the absence of cointegration by any of the possible configurations.

${ }^{27}$ If on the one hand the funds are dispersed in a greater number of borrowers, on the other there are negative effects of concentration in one type of portfolio, less collateral per customer/transaction and higher operating cost per loan, for example.
}

as follows:

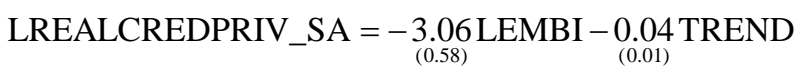

Therefore, the analysis of private banks corroborates the long-term relationship between micro and macro risk.

\subsubsection{Relation between Country Risk and Percentage of Loans to Individuals by Type of Bank}

In periods of economic euphoria, banks tend to look for yield over safety, subjecting their assets to greater perceived risks but higher returns. In economic slumps, the opposite happens: banks direct their assets to less profitable but also less risky operations.

An increase in the concentration of loans to individuals, a priori, causes higher (idiosyncratic) risk of default, mainly due to the profile of these borrowers, who have a greater tendency for nonpayment ${ }^{27}$. According to this pattern, banks should reduce their exposure to personal loans when the structural risk increases.

\subsubsection{Percentage of Loans to Individuals by Public Banks}

The correlation between the percentage of loans to individuals (LPERCINDPUB_SA) by public banks and macroeconomic risk is negative 0.30 . The statistics (Table A.14) determine the number of lags used in the VAR model. Both information criteria used (AIC and SC) indicate only the inclusion of the constant in the cointegration relation, a choice that is validated by visual analysis of the series.

Both the test statistics (trace and maximum eigenvalue) showed in Table A.15 reaffirms the inexistence of a cointegrating relation for public banks.

\subsubsection{Percentage of Loans to Individuals by Private Banks}

For private banks the negative correlation between macroeconomic risk and the percentage of loans to individuals is high (-0.74). The joint analysis of the LR, FPE, AIC, SC and HQ criteria unanimously indicates the number of lags (Table A.16), while in the choice of the deterministic terms, the AIC and SC present conflicting results. The SC indicates only inclusion of the constant in the cointegration relation, while the AIC proposes including an intercept as well in the VAR. However, visual inspection of the series suggests the presence of a linear trend, and hence we chose to follow the Akaike criterion.

The trace and maximum eigenvalue tests evidence the presence of cointegration between the two risk levels 
$\left(\right.$ Table A.17) ${ }^{28}$. Therefore, the Johansen method allows estimating the coefficients of the long-term relation.

$$
\text { LPERCINDPRIV_SA }=\underset{(0.04)}{-0.32} \text { LEMBI }
$$

Once again, the relation is significant and negative for private banks, unlike the pattern for public institutions. Additionally, the results of the negative long-term relation are stronger-in terms of the value of the estimated coefficient - for the sub-sample of private banks than for all banks. Hence, this shows that the relation observed for banks in general is to a great extent influenced by the behavior of private banks.

This different reaction by government-controlled banks in relation to their private peers is coherent with the characteristics of the two types of banks and with the results found in the VEC models. The more rigid definition of the volume of credit by public banks makes them more susceptible to changes in the macroeconomic situation. As observed in the previous sections, the impact on credit risk from macroeconomic factors is more sensitive in the portfolios of public banks. The lesser flexibility of public banks to define the volume of credit and determine the profile of the portfolio restricts their ability to adjust to the macroeconomic environment.

In overall terms, both from the standpoint of origination of loans-used for banks in general-and from the standpoint of exposure to credit risk-broken down by bank type-we found there is an interaction between the economic situation and banks in constitution of credit risk at the portfolio level. This is what composes the spread and determines the average interest rate on loans.

\section{Conclusions}

According to the [7] page 45, in the case of Brazil, where the capital and private bond markets are relatively underdeveloped and restricted to few participants, bank credit has great relevance in financing companies. The high cost of this type of credit, therefore, can have negative implications on the accumulation of capital and technological innovation, and consequently on economic growth.

Generally the diagnoses made in the economic literature point to risk of default as one of the main causes of the high bank spread in Brazil. In this sense, a better understanding of bank credit risk can help in management of economic policy.

This paper investigated the interactive process between the macroeconomic environment and bank credit risk, not only in the way structural factors affect the risk incurred on lending operations, but also banks' reactions

${ }^{28}$ This cointegration relation is reinforced by the fact it exists regardless of the specification chosen. to these effects.

We first observed that macroeconomic factors significantly impact the credit risk incurred by banks. Despite the effects caused by unemployment and monetary tightening, economic growth and the Selic rate stand out as factors affecting this risk.

However, these are not the only effects. Banks are economic agents, and as such they seek to take advantage of the opportunities on offer. To control the idiosyncratic risk involved in lending operations, these institutions can-through active measures-modify the size and/or profile of their loan portfolios. This makes for an interactive process involving banks, credit risk and the macroeconomic environment. Figure 5 structurally summarizes the discussion of the relationship between macroeconomic risk and idiosyncratic risk and its impact on the performance of the economy.

Changes in the macroeconomic scenario affect the average default risk of loan portfolios, which in turn modifies the cost structure, spreads and interest rates charged on loans. As a consequence, the volume of credit changes, implying variations in economic growth-intrinsically related to macroeconomic factors. Nevertheless, this cycle depends on the way banks react to economic fluctuations. Modification of the risk of default by determination of the loan portfolio profile can minimize or even totally offset the effects from the macroeconomic scenario.

We also found evidence of differences in this interactive process according to the type of bank control. Banks in the private sector respond more actively to the impacts of the macroeconomic situation than do public banks, enabling them to better mitigate the effects and manage their loan portfolios more efficiently. Public banks face greater institutional and legal barriers and often political pressures as well that hinder a more active risk management stance.

To a certain extent the characteristics that distinguish each type of bank help explain the differences found in the relevance and significance of the effects caused by each macroeconomic factor, the strength and duration of

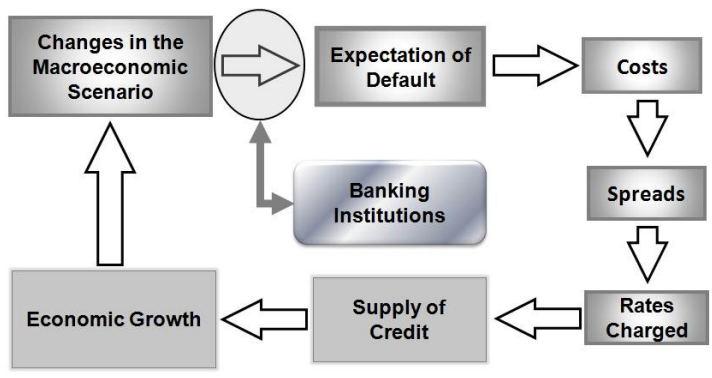

Figure 5. General summary-the interactive process interfering in the economic cycle. 
the impacts caused by economic shocks and the reaction itself to structural oscillations with respect to risk. The reactions measured by exposure to credit risk are significant only for private banks. Being controlled by the government limits the extent of the changes possible in the loan portfolio composition, and at the same time makes the average credit risk of public banks more susceptible to economic variations.

In summary, this paper sought to shed light on bank credit risk in Brazil under new prisms, by examining the lending risk incurred by banks not only as depending on the macroeconomic scenario but also the stance of banks to this risk. This interaction of the macroeconomic environment and banks must be considered at the moment of making economic policy decisions. In terms of regulation, while during crisis moments the defensive posture of banks can hinder reaching the inflection point of renewed growth, in moments of economic expansion the excessive leverage posture can lead to a crisis in the financial sector that spreads to the entire economy it underpins.

\section{References}

[1] Banco Central do Brasil, “Juros e Spread Bancário no Brasil,” 1999. http://www.bcb.gov.br/ftp/juros-spread1.pdf

[2] Banco Central do Brasil, "Relatório de Economia Bancária e Crédito: Avaliação de 1 ano do Projeto Juros e Spread Bancário,” 2000. http://www.bcb.gov.br/ftp/jurospread 112000. pdf

[3] Banco Central do Brasil, "Relatório de Economia Bancária e Crédito: Avaliação de 2 anos do Projeto Juros e Spread Bancário,” 2001.

http://www.bcb.gov.br/ftp/jurospread112001.pdf

[4] Banco Central do Brasil, "Relatório de Economia Bancária e Crédito: Avaliação de 3 anos do Projeto Juros e Spread Bancário,” 2002.

http://www.bcb.gov.br/ftp/jurospread122002.pdf

[5] Banco Central do Brasil, "Relatório de Economia Bancária e Crédito: Avaliação de 4 anos do Projeto Juros e Spread Bancário,” 2003.

http://www.bcb.gov.br/ftp/rel_econmia_bancaria_credito. pdf

[6] Banco Central do Brasil, "Relatório de Economia Bancária e Crédito: Avaliação de 5 anos do Projeto Juros e Spread Bancário,” 2004.

http://www.bcb.gov.br/Pec/spread/port/economia_bancaria _e_credito.pdf

[7] Banco Central do Brasil, "Relatório de Economia Bancária e Crédito. Brasília,” 2005. http://www.bcb.gov.br/pec/spread/port/rel_econ_ban_cre d.pdf

[8] Banco Central do Brasil, "Relatório de Economia Bancária e Crédito,” 2006.
http://www.bcb.gov.br/Pec/spread/port/relatorio_economi a_bancaria_credito.pdf

[9] M. H. Pesaran, T. Schuermann, B. J. Treutler and S. M. Weiner, "Macroeconomic Dynamics and Credit Risk: A Global Perspective,” Journal of Money, Credit and Banking, Vol. 38, No. 5, 2006, pp. 1211-1261.

[10] A. Cunningham, "Rating Methodology: Bank Credit Risk in Emerging Markets-An Analytical Framework,” 1999. http://rating.interfax.ru/data/rating/emerging\%20banks\% 20methodology.pdf

[11] U. S. Census Bureau, "X-12-ARIMA: Reference Manual Version 0.3,” 2007. http://www.census.gov/srd/www/x12 a

[12] D. Kwiatkowski, P. C. B. Phillips, P. Schmidt and Y. Shin, "Testing the Null Hypothesis of Stationary against the Alternative of a Unit Root: How Sure Are We That Economic Time Series Have a Unit Root?,” Journal of Econometrics, Vol. 54, No. 1-3, 1992, pp. 159-178.

[13] G. S. Maddala, “Introduction to Econometrics,” 3rd Edition, John Wiley \& Sons Ltd., Chichester, 2001.

[14] H. Lütkepohl, "New Introduction to Multiple Time Series Analysis,” Springer, Berlin, 2005.

[15] W. H. Greene, "Econometric Analysis,” 4th Edition, Prentice-Hall, Upper Saddle River, 2000.

[16] S. Johansen, "Statistical Analysis of Cointegration Vectors," Journal of Economic Dynamics and Control, Vol. 12, No. 2-3, 1988, pp. 231-54. doi:10.1016/ 0165-1889(88)90041-3

[17] S. Johansen, "Estimation and Hypothesis Testing of Cointegrating Vectors in Gaussian Vector Autoregressive Models,” Econometrica, Vol. 59, No.6, 1991, pp. 15511580. doi:10.2307/2938278

[18] S. G. Hall, “The Effect of Varying Length VAR Models on the Maximum Likelihood Estimates of Cointegrating Vectors," Scottish Journal of Political Economy, Vol. 38, No. 4, 1991, pp. 317-323. doi:10.1111/j. 1467-9485.1991.tb00320.x

[19] D. F. Hendry and K. Juselius, "Explaining Cointegration Analysis: Part I,” Energy Journal, Vol. 21, No.1, 2000, pp. 1-42. doi:10.5547/ISSN0195-6574-EJ-Vol21-No1-1

[20] D. F. Hendry and K. Juselius, "Explaining Cointegration Analysis: Part II,” Energy Journal, Vol. 22, No. 1, 2001, pp. $75-120$. doi:10.5547/ISSN0195-6574-EJ-Vol22-No1-4

[21] R. I. D. Harris, "Using Cointegration Analysis in Econometric Modelling,” 1st Edition, Prentice-Hall, London, 1995.

[22] W. Enders, “Applied Econometric Time Series,” 2nd Edition, John Wiley \& Sons Ltd., New York, 2003.

[23] W. Charemza and D. F. Deadman, "New Directions in Econometric Practice: General to Specific Modelling, Cointegration and Vector Autoregression,” 2nd Edition, Edward Elgar, London, 1997.

[24] M. H. Pesaran and Y. Shin, "Generalized Impulse Re- 
sponse Analysis in Linear Multivariate Models,” Economics Letters, Vol. 58, No. 1, 1998, pp. 17-29.

doi: 10.1016/S0165-1765(97)00214-0

[25] H. F. de Mendonça and G. J. de Guimarães e Souza, “Inflation Targeting Credibility and Reputation: The Conesquences for the Interest Rate," Economic Modelling, Vol. 26, No. 6, 2009, pp. 1228-1238. doi:10. 1016/j.econmod.2009.05.010

[26] J. A. Ocampo, "Developing Countries' Anti-Cyclical Poli- cies in a Globalized World,” Cepal, Santiago, 2002.
[27] T. S. Afanasieff, P. M. Lhacer and M. I. Nakane, "The Determinants of Bank Interest Spread in Brazil,” Money Affairs, Vol. 15, No. 2, 2002, pp. 183-207.

[28] F. J. C. Carvalho, “On Banks’ Liquidity Preference,” In: P. Davidson and J. Kregel., Eds., Full Employment and Price Stability in a Global Economy, 1st Edition, Edward Elgar Publishing, Cheltenham, 1999, pp. 123-138.

[29] J. M. Keynes, "The General Theory of Employment, Interest and Money,” Macmillan Press, Cambridge, 1936. 


\section{Appendix}

Table A.1. Results of the unit root and stationarity tests.

\begin{tabular}{|c|c|c|c|c|c|c|c|c|c|c|c|c|c|c|c|c|}
\hline \multirow[b]{2}{*}{ Series } & \multicolumn{4}{|c|}{ ADF } & \multicolumn{4}{|c|}{ PP } & \multicolumn{4}{|c|}{ DF-GLS } & \multicolumn{4}{|c|}{ KPSS } \\
\hline & Lag & $\begin{array}{c}\text { Determ. } \\
\text { comp. }\end{array}$ & Stat & $\begin{array}{c}\text { Critical } \\
\text { value } \\
10 \%\end{array}$ & Lag & $\begin{array}{c}\text { Determ. } \\
\text { comp. }\end{array}$ & Stat & $\begin{array}{c}\text { Critical } \\
\text { value } \\
10 \%\end{array}$ & Lag & $\begin{array}{c}\text { Determ. } \\
\text { comp. }\end{array}$ & Stat & $\begin{array}{c}\text { Critical } \\
\text { value } \\
10 \%\end{array}$ & Lag & $\begin{array}{c}\text { Determ. } \\
\text { comp. }\end{array}$ & Stat & $\begin{array}{c}\text { Critical } \\
\text { value } \\
10 \%\end{array}$ \\
\hline LRISK1PUB_SA & 0 & $\mathrm{C}$ & -1.83 & -2.59 & 1 & C & -1.77 & -2.59 & 0 & $\mathrm{CT}$ & -1.81 & -2.82 & 6 & $\mathrm{C}$ & 0.21 & 0.35 \\
\hline D(LRISK1PUB_SA) & 0 & $\mathrm{~N}$ & -9.70 & -1.61 & 0 & $\mathrm{~N}$ & -9.70 & -1.61 & 0 & CT & -9.65 & -2.82 & 2 & $\mathrm{C}$ & 0.10 & 0.35 \\
\hline LRISK1PRIV_SA & 1 & $\mathrm{C}$ & -3.37 & -2.59 & 1 & $\mathrm{C}$ & -2.53 & -2.59 & 1 & $\mathrm{CT}$ & -1.74 & -2.82 & 6 & $\mathrm{C}$ & 0.24 & 0.35 \\
\hline D(LRISK1PRIV_SA) & 0 & $\mathrm{~N}$ & -6.65 & -1.61 & 2 & $\mathrm{~N}$ & -6.65 & -1.61 & 0 & CT & -6.44 & -2.82 & 1 & C & 0.25 & 0.35 \\
\hline LSELIC & 1 & C & -3.54 & -2.59 & 6 & $\mathrm{~N}$ & -0.57 & -1.61 & 1 & CT & -2.60 & -2.82 & 6 & $\mathrm{C}$ & 0.13 & 0.35 \\
\hline D(LSELIC) & 0 & $\mathrm{~N}$ & -2.62 & -1.61 & 3 & $\mathrm{~N}$ & -2.91 & -1.61 & 0 & CT & -2.64 & -2.82 & 6 & $\mathrm{C}$ & 0.08 & 0.35 \\
\hline LRESREQ & 0 & $\mathrm{~N}$ & -1.30 & -1.61 & 3 & $\mathrm{~N}$ & -1.26 & -1.61 & 0 & $\mathrm{CT}$ & -1.08 & -2.82 & 6 & $\mathrm{CT}$ & 0.25 & 0.12 \\
\hline D(LRESREQ) & 0 & $\mathrm{~N}$ & -8.41 & -1.61 & 3 & $\mathrm{~N}$ & -8.43 & -1.61 & 0 & CT & -7.61 & -2.82 & 3 & C & 0.21 & 0.35 \\
\hline LSPREAD & 0 & $\mathrm{~N}$ & -0.50 & -1.61 & 2 & $\mathrm{~N}$ & -0.50 & -1.61 & 0 & CT & -1.87 & -2.82 & 6 & $\mathrm{C}$ & 0.19 & 0.35 \\
\hline D(LSPREAD) & 0 & $\mathrm{~N}$ & -9.75 & -1.61 & 1 & $\mathrm{~N}$ & -9.74 & -1.61 & 1 & CT & -2.13 & -2.82 & 2 & C & 0.09 & 0.35 \\
\hline LEMBI & 1 & $\mathrm{~N}$ & -0.78 & -1.61 & 4 & $\mathrm{~N}$ & -0.73 & -1.61 & 1 & $\mathrm{CT}$ & -1.90 & -2.82 & 6 & $\mathrm{CT}$ & 0.23 & 0.12 \\
\hline D(LEMBI) & 0 & $\mathrm{~N}$ & -4.94 & -1.61 & 2 & $\mathrm{~N}$ & -5.02 & -2.59 & 0 & CT & -4.69 & -2.82 & 4 & C & 0.21 & 0.35 \\
\hline LUNEMP_SA & 1 & $\mathrm{~N}$ & -0.01 & -1.61 & 3 & $\mathrm{~N}$ & -0.02 & -1.61 & 1 & CT & -1.76 & -2.82 & 6 & $\mathrm{C}$ & 0.28 & 0.35 \\
\hline D(LUNEMP_SA) & 0 & $\mathrm{~N}$ & -5.92 & -1.61 & 12 & $\mathrm{~N}$ & -5.74 & -1.61 & 0 & CT & -5.89 & -2.82 & 3 & $\mathrm{C}$ & 0.16 & 0.35 \\
\hline LOUTPUT_SA & 3 & CT & -2.80 & -3.61 & 5 & CT & -4.64 & -3.16 & 3 & CT & -2.84 & -2.82 & 6 & $\mathrm{CT}$ & 0.18 & 0.12 \\
\hline D(LOUTPUT_SA) & 1 & $\mathrm{~N}$ & -8.98 & -1.61 & 3 & $\mathrm{~N}$ & -13.91 & -1.61 & 1 & CT & -9.21 & -2.82 & 4 & $\mathrm{C}$ & 0.05 & 0.35 \\
\hline LLENDTOASSETS_SA & 2 & $\mathrm{~N}$ & 0.43 & -1.61 & 6 & CT & -6.21 & -3.16 & 2 & СТ & -1.47 & -2.82 & 6 & CT & 0.12 & 0.12 \\
\hline D(LLENDTOASSETS_SA) & 1 & $\mathrm{~N}$ & -11.55 & -1.61 & 5 & $\mathrm{~N}$ & -20.55 & -1.61 & 1 & CT & -9.78 & -2.82 & 4 & C & 0.14 & 0.35 \\
\hline LPERLOANIND_SA & 0 & $\mathrm{C}$ & -2.34 & -2.59 & 3 & $\mathrm{C}$ & -2.12 & -2.59 & 0 & CT & -3.40 & -2.82 & 6 & C & 0.79 & 0.35 \\
\hline D(LPERLOANIND_SA ) & 1 & $\mathrm{~N}$ & -8.49 & -1.61 & 3 & $\mathrm{~N}$ & -10.45 & -1.61 & 1 & $\mathrm{CT}$ & -8.38 & -2.82 & 4 & $\mathrm{C}$ & 0.08 & 0.35 \\
\hline LREALCREDPUB_SA & 2 & $\mathrm{~N}$ & 0.65 & -1.61 & 1 & $\mathrm{~N}$ & -0.83 & -1.61 & 3 & CT & -1.57 & -2.82 & 6 & $\mathrm{CT}$ & 0.24 & 0.12 \\
\hline D(LREALCREDPUB_SA) & 1 & $\mathrm{~N}$ & -7.68 & -1.61 & 2 & $\mathrm{~N}$ & -7.00 & -1.61 & 1 & CT & -7.99 & -2.82 & 1 & $\mathrm{C}$ & 0.22 & 0.35 \\
\hline LREALCREDPRIV_SA & 3 & CT & -2.91 & -3.16 & 6 & $\mathrm{~N}$ & -4.72 & -1.61 & 3 & CT & -2.10 & -2.82 & 6 & $\mathrm{CT}$ & 0.13 & 0.12 \\
\hline D(LREALCREDPRIV_SA) & 1 & $\mathrm{C}$ & -3.38 & -2.59 & 5 & $\mathrm{C}$ & -7.11 & -2.59 & 1 & CT & -3.39 & -2.82 & 6 & $\mathrm{C}$ & 0.19 & 0.35 \\
\hline LPERCINDPUB_SA & 0 & $\mathrm{C}$ & -3.05 & -2.59 & 4 & $\mathrm{C}$ & -3.17 & -2.59 & 0 & CT & -1.18 & -2.82 & 6 & $\mathrm{CT}$ & 0.16 & 0.12 \\
\hline D(LPERCINDPUB_SA) & 0 & $\mathrm{~N}$ & -7.66 & -1.61 & 0 & $\mathrm{~N}$ & -7.66 & -1.61 & 0 & CT & -8.11 & -2.82 & 1 & C & 0.41 & 0.35 \\
\hline LPERCINDPRIV_SA & 0 & $\mathrm{~N}$ & -5.07 & -1.61 & 5 & $\mathrm{~N}$ & -3.69 & -1.61 & 0 & CT & -1.22 & -2.82 & 6 & $\mathrm{CT}$ & 0.19 & 0.12 \\
\hline D(LPERCINDPRIV_SA) & 1 & $\mathrm{C}$ & -4.04 & -2.59 & 4 & $\mathrm{C}$ & -7.69 & -2.59 & 1 & $\mathrm{C}$ & -3.06 & -1.61 & 5 & $\mathrm{C}$ & 0.12 & 0.35 \\
\hline
\end{tabular}

Notes: $\mathrm{D}(\mathrm{)})$ is the first difference. The deterministic components are: $\mathrm{C}=$ Constant and Linear Trend. In the ADF and DF-GLS tests, the number of lags used was defined according to the Schwaz criterion. For the PP and KPSS tests we applied selection by Newey-West estimates.

Table A.2. Lag selection criteria-public banks.

\begin{tabular}{cccccc}
\hline Lags & LR & FPE & AIC & SC & HQ \\
\hline 0 & NA & 0.00 & -17.78 & -17.59 & -17.70 \\
1 & 711.24 & 0.00 & -27.72 & -26.39 & -27.19 \\
2 & $153.27^{*}$ & $0.00^{*}$ & $-29.32^{*}$ & $-26.85^{*}$ & $-28.33^{*}$ \\
3 & 46.58 & 0.00 & -29.20 & -25.59 & -27.76 \\
4 & 43.14 & 0.00 & -29.11 & -24.37 & -27.23 \\
\hline
\end{tabular}

Notes: The variables used are: Credit Risk (Public Banks), Unemployment, Output, Selic, Reserve Requirement and Spread. The sample corresponds to the period from March 2000 to June 2006. For the LR, each sequential test uses 5\%. (*) Indicates the lag selected by the criterion. 
Table A.3. Criterion for ordering the variables-public banks.

\begin{tabular}{|c|c|c|c|c|c|c|c|c|c|c|c|c|}
\hline & \multicolumn{12}{|c|}{ Dependent Variable } \\
\hline & \multicolumn{2}{|c|}{ Unemployment } & \multicolumn{2}{|c|}{ Output } & \multicolumn{2}{|l|}{ Selic } & \multicolumn{2}{|c|}{ Reserve Requirement } & \multicolumn{2}{|c|}{ Credit Risk (Public) } & \multicolumn{2}{|c|}{ Spread } \\
\hline & Chi-square & Prob. & Chi-square & Prob. & Chi-square & Prob. & Chi-square & Prob. & Chi-square & Prob. & Chi-square & Prob. \\
\hline Unemployment & - & - & 1.87 & 0.17 & 0.00 & 1.00 & 1.95 & 0.16 & 1.85 & 0.17 & 1.07 & 0.30 \\
\hline Output & 4.68 & 0.03 & - & - & 0.13 & 0.72 & 0.09 & 0.76 & 3.96 & 0.05 & 2.54 & 0.11 \\
\hline SELIC & 0.13 & 0.72 & 0.00 & 0.96 & - & - & 0.00 & 0.98 & 7.99 & 0.00 & 15.45 & 0.00 \\
\hline Reserve Requirement & 0.72 & 0.40 & 1.73 & 0.19 & 3.52 & 0.06 & - & - & 14.69 & 0.00 & 14.84 & 0.00 \\
\hline Credit Risk (Public) & 0.37 & 0.54 & 3.19 & 0.07 & 0.42 & 0.52 & 0.21 & 0.65 & - & - & 4.73 & 0.03 \\
\hline Spread & 0.15 & 0.70 & 2.03 & 0.15 & 2.81 & 0.09 & 4.70 & 0.03 & 9.78 & 0.00 & - & - \\
\hline Total & 5.35 & 0.37 & 6.64 & 0.25 & 6.77 & 0.24 & 9.87 & 0.08 & 33.25 & 0.00 & 35.95 & 0.00 \\
\hline
\end{tabular}

Note: Probability values calculated by Eviews 5 .

Table A.4. Lag selection criteria-private banks.

\begin{tabular}{|c|c|c|c|c|c|}
\hline Lags & LR & FPE & AIC & SC & HQ \\
\hline 0 & NA & 0.00 & -19.54 & -19.35 & -19.47 \\
\hline 1 & 692.68 & 0.00 & -29.20 & -27.87 & -28.67 \\
\hline 2 & 135.01 & 0.00 & $-30.54^{*}$ & $-28.02^{*}$ & $-29.51^{*}$ \\
\hline 3 & $55.95^{*}$ & $0.00^{*}$ & -30.49 & -26.94 & -29.11 \\
\hline
\end{tabular}

Notes: The variables used are: Credit Risk (Private Banks), Unemployment, Output, Selic, Reserve Requirement and Spread. The sample corresponds to the period from March 2000 to June 2006. For the LR, each sequential test uses 5\%. (*) Indicates the lag selected by the criterion.

Table A.5. Criterion for ordering the variables—private banks.

\begin{tabular}{|c|c|c|c|c|c|c|c|c|c|c|c|c|}
\hline & \multicolumn{12}{|c|}{ Dependent Variable } \\
\hline & \multicolumn{2}{|c|}{ Reserve Requirement } & \multicolumn{2}{|c|}{ t Unemployment } & \multicolumn{2}{|c|}{ Selic } & \multicolumn{2}{|c|}{ Output } & \multicolumn{2}{|c|}{ Spread } & \multicolumn{2}{|c|}{ Credit Risk (Private) } \\
\hline & Chi-square & Prob. & Chi-square & Prob. & Chi-square & Prob. & Chi-square & Prob. & Chi-square & Prob. & Chi-square & Prob. \\
\hline Reserve Requirement & - & - & 3.50 & 0.06 & 5.24 & 0.02 & 1.00 & 0.32 & 7.44 & 0.01 & 0.04 & 0.84 \\
\hline Unemployment & 1.92 & 0.17 & - & - & 0.24 & 0.63 & 2.20 & 0.14 & 2.62 & 0.11 & 16.04 & 0.00 \\
\hline Selic & 0.07 & 0.80 & 0.23 & 0.63 & - & - & 2.79 & 0.10 & 13.59 & 0.00 & 9.38 & 0.00 \\
\hline Output & 0.99 & 0.32 & 3.95 & 0.05 & 1.06 & 0.30 & - & - & 0.11 & 0.74 & 10.21 & 0.00 \\
\hline Spread & 7.19 & 0.01 & 0.13 & 0.72 & 1.70 & 0.19 & 5.17 & 0.02 & - & - & 6.58 & 0.01 \\
\hline Credit Risk (Private) & 0.34 & 0.56 & 4.61 & 0.03 & 5.81 & 0.02 & 0.00 & 0.99 & 0.13 & 0.71 & - & - \\
\hline Total & 12.40 & 0.03 & 12.96 & 0.02 & 13.90 & 0.02 & 15.73 & 0.01 & 23.16 & 0.00 & 29.59 & 0.00 \\
\hline
\end{tabular}

Note: The probabilities were calculated by Eviews 5 .

Table A.6. Lag selection criteria-loans divided by bank assets.

\begin{tabular}{cccccc}
\hline Lags & LR & FPE & AIC & SC & HQ \\
0 & NA & 0.00 & -0.88 & -0.81 & -0.85 \\
1 & 198.37 & 0.00 & -3.95 & -3.75 & -3.87 \\
2 & $23.88^{*}$ & 0.00 & -4.23 & $-3.90^{*}$ & $-4.10^{*}$ \\
3 & 7.32 & $0.00^{*}$ & $-4.23^{*}$ & -3.76 & -4.05 \\
4 & 0.45 & 0.00 & -4.12 & -3.52 & -3.88 \\
\hline
\end{tabular}

Notes: The variables are: Percentage of Loans Divided by Assets and Country Risk. The sample corresponds to the period from March 2000 to June 2006 . For the LR, each sequential test uses $5 \%$. (*) Indicates the lag selected by the criterion. 
Table A.7. Trace statistics and maximum eigenvalue—-loans divided by bank assets.

\begin{tabular}{|c|c|c|c|}
\hline Null Hypothesis: No. of Cointegrating Vectors & Eigenvalue & Test Statistic & $5 \%$ Critical Value \\
\hline & & Trace & \\
\hline None ${ }^{*}$ & 0.24 & 20.87 & 20.26 \\
\hline \multirow[t]{2}{*}{ At most 1} & 0.02 & 1.79 & 9.16 \\
\hline & & Maximum Eigenvalue & \\
\hline None $^{*}$ & 0.24 & 19.09 & 15.89 \\
\hline
\end{tabular}

Notes: Sample adjusted from August 2000 to June 2006. (*) Denotes rejection of the hypothesis at the 5\% level.

Table A.8. Lag selection criteria-loans to individuals.

\begin{tabular}{|c|c|c|c|c|c|}
\hline Lags & LR & FPE & AIC & SC & HQ \\
\hline 0 & NA & 0,00 & $-3,57$ & $-3,50$ & $-3,54$ \\
\hline 1 & 227.65 & 0.00 & -7.11 & -6.91 & -7.04 \\
\hline 2 & $22.03^{*}$ & $0.00^{*}$ & $-7.36^{*}$ & $-7.02^{*}$ & $-7.23^{*}$ \\
\hline 3 & 2.84 & 0.00 & -7.28 & -6.82 & -7.10 \\
\hline 4 & 0.22 & 0.00 & -7.17 & -6.56 & -6.93 \\
\hline
\end{tabular}

Notes: The variables are: Percentage of Loans to Individuals and Country Risk. The sample corresponds to the period from March 2000 to June 2006 . For the LR, each sequential test uses $5 \%$. (*) Indicates the lag selected by the criterion.

Table A.9. Trace statistics and maximum eigenvalue--loans to individuals.

\begin{tabular}{|c|c|c|c|}
\hline Null Hypothesis: No. of Cointegrating Vectors & Eigenvalue & Test Statistic & $5 \%$ Critical Value \\
\hline & & Trace & \\
\hline None ${ }^{*}$ & 0.23 & 20.45 & 20.26 \\
\hline \multirow[t]{2}{*}{ At most 1} & 0.02 & 1.70 & 9.16 \\
\hline & & Maximum Eigenvalue & \\
\hline None ${ }^{*}$ & 0.23 & 18.75 & 15.89 \\
\hline At most 1 & 0.02 & 1.70 & 9.16 \\
\hline
\end{tabular}

Notes: Sample adjusted from August 2000 to June 2006. $(*)$ Denotes rejection of the hypothesis at the 5\% level.

Table A.10. Lag selection criteria-lending by public banks.

\begin{tabular}{|c|c|c|c|c|c|}
\hline Lags & LR & FPE & AIC & SC & HQ \\
\hline 0 & NA & 0.01 & 1.22 & 1.28 & 1.24 \\
\hline 1 & 407.16 & 0.00 & -4.57 & -4.38 & -4.50 \\
\hline 2 & $23.88^{*}$ & $0.00^{*}$ & $-4.82^{*}$ & $-4.50^{*}$ & $-4.69^{*}$ \\
\hline 3 & 6.44 & 0.00 & -4.81 & -4.36 & -4.63 \\
\hline 4 & 4.45 & 0.00 & -4.77 & -4.20 & -4.54 \\
\hline
\end{tabular}

Notes: The variables are: Real Lending by Public Banks and Country Risk. The sample corresponds to the period from March 2000 to June 2006. For the LR, each sequential test uses $5 \%$. $(*)$ Indicates the lag selected by the criterion.

Table A.11. Trace statistics and maximum eigenvalue—-lending by public banks.

\begin{tabular}{ccc} 
Null Hypothesis: No. of Cointegrating Vectors & Eigenvalue & Test Statistic \\
\hline None & 0.09 & Trace \\
\cline { 2 - 3 } At most 1 & 0.03 & 9.38 \\
None & & 2.29 \\
\hline At most 1 & 0.09 & Maximum Eigenvalue \\
\hline
\end{tabular}

Notes: Sample adjusted from August 2000 to June 2006. (*) Denotes rejection of the hypothesis at the 5\% level. 
Table A.12. Lag selection criteria-lending by private banks.

\begin{tabular}{cccccc}
\hline Lags & LR & FPE & AIC & SC & HQ \\
0 & NA & 0.00 & -0.12 & -0.0555 & -0.09 \\
1 & 447.42 & 0.00 & -6.89 & -6.6906 & -6.81 \\
2 & 23.91 & 0.00 & -7.15 & $-6.8220^{*}$ & $-7.02^{*}$ \\
3 & 9.71 & $0.00^{*}$ & $-7.19^{*}$ & -6.7330 & -7.01 \\
4 & 3.93 & 0.00 & -7.14 & -6.5514 & -6.91 \\
\hline
\end{tabular}

Notes: The variables are: Real Lending of Private Banks and Country Risk. The sample corresponds to the period from March 2000 to June 2006 . For the LR, each sequential test uses $5 \%$. $(*)$ Indicates the lag selected by the criterion.

Table A.13. Trace statistics and maximum eigenvalue—-lending by private banks.

$5 \%$ Critical Value

\begin{tabular}{cccc}
\hline & & Trace & 25.87 \\
\cline { 3 - 3 } None* & 0.29 & 27.88 & 2.90 \\
At most 1 & 0.04 & Maximum Eigenvalue & 12.52 \\
\cline { 3 - 3 } None $^{*}$ & & 24.99 & 19.39 \\
At most 1 & 0.29 & 2.90 & 12.52 \\
\hline
\end{tabular}

Notes: Sample adjusted from August 2000 to June 2006. (*) Denotes rejection of the hypothesis at the $5 \%$ level.

Table A.14. Lag selection criteria-percentage of loans to individuals by public banks.

\begin{tabular}{cccccc}
\hline Lags & LR & FPE & AIC & SC & HQ \\
\hline 0 & NA & 0.00 & -0.08 & -0.01 & -0.05 \\
1 & 348.60 & 0.00 & -5.33 & -5.13 & -5.25 \\
2 & $20.86^{*}$ & $0.00^{*}$ & $-5.54^{*}$ & $-5.21^{*}$ & $-5.41^{*}$ \\
3 & 3.14 & 0.00 & -5.47 & -5.02 & -5.29 \\
4 & 5.04 & 0.00 & -5.44 & -4.85 & -5.21 \\
\hline
\end{tabular}

Notes: The variables are: Percentage of Loans to Individuals of Public Banks and Country Risk. The sample corresponds to the period from March 2000 to June 2006. For the LR, each sequential test uses 5\%. (*) Indicates the lag selected by the criterion.

Table A.15. Trace statistics and maximum eigenvalue—percentage of lending to individuals by public banks.

\begin{tabular}{cccc}
\hline & & Trace & 20.26 \\
None & 0.19 & 17.18 & 9.16 \\
At most 1 & 0.03 & Maximum Eigenvalue & 1.98 \\
None & & 15.20 & 15.89 \\
At most 1 & 0.19 & 1.98 & 9.16 \\
\hline
\end{tabular}

Notes: Sample adjusted from August 2000 to June 2006. $(*)$ Denotes rejection of the hypothesis at the $5 \%$ level.

Table A.16. Lag selection criteria—percentage of lending to individuals by private banks.

\begin{tabular}{cccccc}
\hline Lags & LR & FPE & AIC & SC & HQ \\
\hline 0 & NA & 0.00 & -0.68 & -0.61 & -0.65 \\
1 & 449.83 & 0.00 & -7.48 & -7.28 & -7.40 \\
2 & $25.46^{*}$ & $0.00^{*}$ & $-7.77^{*}$ & $-7.44^{*}$ & $-7.64^{*}$ \\
3 & 6.26 & 0.00 & -7.75 & -7.29 & -7.57 \\
4 & 1.67 & 0.00 & -7.66 & -7.07 & -7.43 \\
\hline
\end{tabular}

Notes: The variables are: Percentage of Loans to Individuals of Private Banks and Country Risk. The sample corresponds to the period from March 2000 to June 2006. For the LR, each sequential test uses 5\%. $\left(^{*}\right)$ Indicates the lag selected by the criterion. 
Table A.17. Trace statistics and maximum eigenvalue—percentage of lending to individuals by private banks.

\begin{tabular}{cccc} 
Null Hypothesis: Number of Cointegrating Vectors & Eigenvalue & Test Statistic & Trace \\
\hline & & 25.91 \\
None $^{*}$ & 0.29 & 0.50 \\
At most 1 & 0.01 & Maximum Eigenvalue & 3.84 \\
\hline & & 25.41 \\
None & 0.29 & 0.50 \\
\hline
\end{tabular}

Notes: Sample adjusted from August 2000 to June 2006. (*) Denotes rejection of the hypothesis at the 5\% level. 